\title{
Influence of Perlite and Jiffy Substrates on Cucumber Fruit Productivity and Quality
}

\author{
Sorin N. Petre ${ }^{1}$, Maria Pele ${ }^{1} \&$ Elena Maria Draghici ${ }^{2}$ \\ 1 Department of Biotechnologies, University of Agronomic Sciences and Veterinary Medicine, Bucharest, \\ Romania \\ ${ }^{2}$ Department of Horticulture, University of Agronomic Sciences and Veterinary Medicine, Bucharest, Romania \\ Correspondence: Maria Pele, Department of Biotechnologies, University of Agronomic Sciences and Veterinary \\ Medicine, 59 Marasti Bd., District 1, Bucharest 011464, Romania. Tel: 40-747-145-741. E-mail: \\ mpele50@yahoo.com
}

Received: April 25, 2015 Accepted: May 25, 2015 Online Published: July 15, 2015

doi:10.5539/jas.v7n8p185 URL: http://dx.doi.org/10.5539/jas.v7n8p185

\begin{abstract}
Most studies related to the culture of cucumbers refer only to germination, emergence and development of leaves and fruit, the nutrients used and their efficiency. This study assesses the influence of different types of soilless substrates (Perlite $-2 \mathrm{~mm}$, Perlite $-4 \mathrm{~mm}$, Perlite $-5 \mathrm{~mm}$, Jiffy and Jiffy $+50 \%$ Perlite $-4 \mathrm{~mm}$ ) on the content of nitrate, carbohydrates, chlorophyll, proteins, invertase activity and dry matter in cucumber leaves, stems and fruit grown on the respective substrates. The highest production was obtained on Perlite $-4 \mathrm{~mm}$. The nitrates content was below the maximum admitted limit for all samples. Dry matter content of fruit depended on substrate in succession Jiffy, Perlite $-5 \mathrm{~mm}$, Perlite $4 \mathrm{~mm}$, Perlite $2 \mathrm{~mm}$ and Jiffy+Perlite $4 \mathrm{~mm}$. The highest content of total chlorophyll was both in leaves as well as relating to fruit of plants grown on Perlite $5 \mathrm{~mm}$. The protein concentrations in fruits decrease in the order Jiffy, Perlite $-4 \mathrm{~mm}$, Perlite $-5 \mathrm{~mm}$, Perlite $-2 \mathrm{~mm}$ and Jiffy + Perlite $-4 \mathrm{~mm}$. Both carbohydrates and invertase activity have the highest values in fruits. When, reducing sugars content is very high invertase activity corresponding is low. The highest level of reducing sugars was found in fruits grown on Jiffy followed by those developed on Perlite $-2 \mathrm{~mm}$. Although, Jiffy substrate shows very good results it is expensive so the best choice for growing cucumbers in terms of both production and nutrient content is mainly the Perlite $-4 \mathrm{~mm}$ substrate.
\end{abstract}

Keywords: carbohydrate, chlorophyll, cucumber, dry matter, invertase, nitrates, protein, production, soilless culture substrate

\section{Introduction}

\subsection{Importance of Cucumber Soilless Cultures}

Demographic growth and reduced cultivation areas has led to recognition of the need for finding new ways to safely cultivating vegetables or fruit. In this context, the recent decades show a widespread development of soilless crops. Therefore, in greenhouses have been developed various types of culture substrates for intensive production.

Cucumbers are some of the vegetables with large consumer demand during the entire year so have to be grown in greenhouses virtually worldwide. For greenhouse cucumber crops in conventional system the soil, is necessary to have a light texture to ensure a root aeration and good drainage. Since the crops on soil show major problems due to pathogen attacks, it is required to conduct soil disinfection using either chemical or thermal method. These methods of disinfection are either too expensive, or too polluting to the soil. In addition, in conventional culture systems cucumber productions obtained are significantly lower than in systems where cucumbers are grown on soilless nutrient substrates.

In addition to, their high productivity, the culture substrates offers the possibility to obtain fruits also in winter and in early spring periods. At the same time a careful controll of nutrients leads to chemically unpolluted quality fruits. Also, the substrates can be reused through recycling.

A number of studies have been conducted regarding the influence of the substrate type on the production of cucumbers grown in the greenhouse in soilless systems have been conducted. Some articles show that the nature of the culture media has great influence on the cucumbers production (Ghehsareh, Hematian, \& Kalbasi, 2012; Shaw, 
Cantlife, Funes, \& Shine, 2004; Gül, 1999). For example Shaw and collaborators compared production and cost price for cultivating cucumber on three types of substrate: coarse-grade perlite, medium-grade perlite and pine bark. This study showed that the marketable fruit weight was not affected by media but was noted that the cost price for Pine bark is substantially lower than that of perlite (Shaw et al., 2004).

Perlite is a natural occurring volcanic glass which is mainly comprised of $\mathrm{SiO}_{2}(70-75 \%)$ with around $13 \% \mathrm{Al}_{2} \mathrm{O}_{3}$ and smaller concentration of $\mathrm{Fe}_{2} \mathrm{O}_{3}, \mathrm{MgO}, \mathrm{Na}_{2} \mathrm{O}, \mathrm{K}_{2} \mathrm{O}, \mathrm{CaO}$ and up to $5 \%$ linked chemically or combined water (Herskovitch \& Lin, 1996). Due to its properties, namely, its high pore volume, with good water retention ability, and being chemically inert and totally environmentally friendly, perlite is an ideal substrate in soilless crops. In addition, in Romania, due to its availability and the lowest price compared to other substrates Perlite is the most convenient substrate for use. However given the diversity of existing perlite in trade, it is necessary to choose the best Perlite choice for a culture, by taking into account the behavior of the plant that will be cultivated.

Coconut fibers are marketed in Romania for use in horticulture under the name Jiffy. This substrate is most commonly used so far in soilless crops especially due to its properties: It is organic, inert, absorbs heat and has no pathogens or weed seeds.

\subsection{Quality of Fruits}

Most often fruits obtained in soilless crops have no taste, flavor, unctuousness to those grown in the garden or in the field. These, although they look very nice, have frequently a watery taste, unsubstantial.

Therefore, it is important to know the best substrates that provide the right assimilation capacity of compounds which give consistency, texture and lubricity to fruits (for example proteins and carbohydrates) similar to those growed in the field or garden.

Most publications on growing cucumbers in greenhouses relates how culture conditions (temperature, light, $\mathrm{pH}$, nutrients, nature of the substrate, irrigation, etc.) influences the fruits production and appearance of the fruit (size, weight, color) (Hochmuth, 2012; Shaw et al., 2004).

Some of the substances that give cucumber fruit nutritional quality are sugar, protein and dry matter, but a correlation between these substances and different culture substrates is very little studied and literature on this subject is virtually nonexistent. For example there are studies that evaluate the influence of temperature and light on sugar content and on the enzyme that catalyzes the hydrolysis of sucrose to the corresponding monomers glucose and fructose, but comparative studies which pursuit the evolution of these compounds depending on the growth of cucumber on different substrates were not found (Mi, Liu, Zhang, \& Ren, 2012; L. N. Wang, Yang, Ren, \& X. F. Wang, 2014; Rybus-Zając, Kubiś, \& Bocianowski, 2014).

In addition, the chlorophyll content which is an indicator of the ability to synthesize different substances necessary for the plant development was studied in relation to different external factors or absorption of minerals but not in conjunction with the various culture substrates (Inthichack, Nishimura, \& Fukumoto, 2014).

One problem that sometimes occurs in soilless cucumber culture is the lack of sufficient oxygen due to the reduced culture vessel volume and is manifested by restricted root growth with a possible increased the starch concentrations along with a reduction of reducing sugars biosynthesis in cucumber leaves (Robbins \& Pharr, 1988).

Nevertheless, although studies have been conducted on the effect of various factors on the content of biochemical compounds, practically studies on the effect of different soilless culture substrates on the cucumber composition are really very few, almost missing.

\subsection{The Aim of the Study}

A series of studies on the relationship between environmental factors and cucumber fruits productivity in soilless culture on different substrates, were performed. However, most of the studies focus on fruits productivity and appearance. In most cases soilless crops lead to healthy vigorous plants, and high yields. Nevertheless, a very few comparative studies have evaluated the nutritional fruit quality obtained on different categories of culture substrates in terms of the content of substances such as, nitrates, dry matter, reducing sugars or protein. Thus, the objectives of this study were to investigate the content of nitrates, reducing sugars, chlorophyll, proteins, invertase activity and dry matter in leaves, stems and fruits from cucumbers grown on different types of perlite and coconut fiber (named Jiffy) soilless substrates. 


\section{Materials and Methods}

\subsection{Experimental Design}

The experiments were performed with Pyralis variety cucumber (Cucumis sativus L.).

The substrates used to experiment were Perlite with different grain sizes ( $2 \mathrm{~mm}, 4 \mathrm{~mm}$ and $5 \mathrm{~mm}$ ) and Jiffy. These substrates were chosen to evaluate the productivity and quality of cucumber fruit grown on Perlite compared to currently used substrate (Jiffy). Reason this comparison is on one hand in that Perlite is widely available in Romania and, on the other hand, its price is much lower than of the coconut fibers substrates which are imported.

Cucumber seedlings were obtained by sowing in pots filled with perlite in warm greenhouse. The pots had $10 \mathrm{~cm}$ in diameter and $5 \mathrm{~cm}$ height. Perlite used to fill the pots had a grain size of $4 \mathrm{~mm}$ (Perlite $-4 \mathrm{~mm}$ ). Nutrient solution had an EC of 0.7 and a pH of 5.8. Greenhouse temperature was set to $23-24{ }^{\circ} \mathrm{C}$ during the day and to $17-18{ }^{\circ} \mathrm{C}$ during the night. Seedlings were watered daily with nutrient solution.

At planting on matresses cucumber seedlings have had the age of 30 days after sowing, five true leaves and a mean height of $23 \mathrm{~cm}$.

Cucumber cultures were performed in a common greenhouse with glass walls and roof.

Field experiments were conducted on soilless 30 liters capacity $1 \mathrm{~m}$ long systems on mattresses. The properties of the substrate for each mattress used are presented in Table 1.

Table 1. Physiochemical properties of substrates

\begin{tabular}{|c|c|c|c|c|c|c|}
\hline & \multicolumn{2}{|c|}{ Bulk Density, $\mathrm{kg} / \mathrm{m}^{3}$} & \multirow{2}{*}{ Moisture Capacity } & \multirow{2}{*}{ Total Porosity, $\%$} & \multirow{2}{*}{ Air Porosity, $\%$} & \multirow{2}{*}{$\mathrm{pH}$} \\
\hline & Dry & Wet & & & & \\
\hline Perlite $2 \mathrm{~mm}$ & 58 & 91.6 & 50 & 72.3 & 31 & 7.1 \\
\hline Perlite $4 \mathrm{~mm}$ & 83 & 114 & 37 & 75 & 36 & 7.1 \\
\hline Perlite $5 \mathrm{~mm}$ & 45 & 87 & 45 & 83 & 40.8 & 7.1 \\
\hline Jiffy & 87 & 180 & 84 & 83 & 34 & 5.5 \\
\hline Jiffy + Perlite $4 \mathrm{~mm}$ (each $50 \%)$ & 74 & 93 & 43 & 91 & 38 & 6.5 \\
\hline
\end{tabular}

On each mattress three seedlings of cucumber were planted. Cultures were developed between February 15th and May 15th, 2014. In February and March the enlightenment was supplemented with light provided by halogen lamps between 6 and 8 am and 17 and 19 pm. In April and May cultures have been developed without supplementary lighting.

The temperature was maintained both in substrate as well as in air at about $18{ }^{\circ} \mathrm{C}$ during the night and at $23{ }^{\circ} \mathrm{C}$ during the day. The culture fertilization was always the same for all types of substrate. Thus, for the first 30 days of growth usual fertilizing solution contained calcium nitrate, potassium nitrate, chelated iron, potassium sulphate and microelements having the $\mathrm{pH}$ of 5.6 and $\mathrm{EC}$ of $2.6 \mathrm{mS} / \mathrm{cm}$. The fertilizer solution for the next period was composed of potassium nitrate, potassium monophosphate, magnesium sulphate, boron, copper, zinc, molybdenum with a $\mathrm{pH}$ of 5.5 and $\mathrm{EC}$ of $2.6-3.0 \mathrm{mS} / \mathrm{cm}$.

After a three-month growth, cucumber crops were harvested. Average samples of stems, leaves and fruits were harvested fromcrops which were obtained for each substrate in part. Each sample was homogenized very well in order to obtain 15 uniformly milled tissue samples thus that ground to pass a $2 \mathrm{~mm}$ screen. These samples of homogeneous grounded tissues were used to carry out various analyzes.

\subsection{Assay of Nitrate Content}

The nitrate concentrations were determined by phenoldisulfonic acid method using phenol-2,4-disulphonic acid in basic medium (sodium hydroxide, 20\%). The resulting Nitro-derivatives give a yellow color, read at $420 \mathrm{~nm}$, whose intensity is proportional to the concentration of nitrate in the alayzed samples (Palanna, 2009).

\subsection{Assay of Dry Matter Content}

Evaluation of dry matter has been accomplished using the ISO 751 (1998) method.

\subsection{Assay of Chlorophyll Content}

The chlorophylls content was determined by the method of Moran (1982). Pigment concentrations were calculated 
using the equations adapted from Moran (1982) and Inskeep and Bloom (1985).

\subsection{Assay of Proteins Content}

The modified Hartree-Lowry method using bovine serum albumine as a standard was used to assess the total soluble protein (Lowry, Rosenbrough, Farr, \& Randall, 1951; Hartree, 1972). This method is based on the formation of a cupric compound, when the protein react with an alkaline copper reagent (Biuret reaction) forming a blue complex. In the second stage this complex is reduced by phosphomolybdate and phosphotungstate from the Folin - Ciocalteu reagent by heating for 10 minutes at $50{ }^{\circ} \mathrm{C}$. The intensity of colour is read at $660 \mathrm{~nm}$ and the protein content is determined using a standard curve. Extraction of proteins was achieved by accurate weighing 10 $\mathrm{g}$ of plant material, passing it into $100 \mathrm{ml}$ volumetric flask, bring up to volume by adding distilled water, letting it in rest for 1 hour followed by filtration. The protein content was determined in $1 \mathrm{ml}$ samples of the filtrate achieved from.

\subsection{Assay of Total Reducing Sugars Content}

Reducing sugars determination was performed by the DNS method (Miller, 1959).

\subsection{Assay of Invertase Activity}

Invertase activity was determined using the updated method by Wang (2009) where dinitrosalicylic acid reagent was added to stop the hydrolysis reaction catalyzed by invertase and to react with the reducing sugars resulted. One unit of invertase (IU) is defined as the amount of enzyme which liberates $1 \mu$ moles of glucose/hour $/ \mathrm{ml}$ under the assay condition at a $\mathrm{pH}$ of 7 . Invertase activity was determined in $1 \mathrm{ml}$ of filtrate prepared to determine the carbohydrates content. The specific activity was calculated by dividing invertase activity by the total protein concentration in that same time point (measured in $\mathrm{mg} / \mathrm{ml}$ ).

All spectrophotometric measurements were made by using a Metertek SP830 Plus UV-VIS scanning spectrophotometer, calibrated at $705 \mathrm{~nm}$, using the $0.2 \mathrm{~nm}$ width measuring band beam and $1 \mathrm{ml}$ cuvette having a path length of $1 \mathrm{~cm}$.

Data were analyzed by an analysis of variance $(\mathrm{P}<0.05)$ and means separated by Duncan's multiple range tests using Statistical Analysis System. Each biochemical assay was performed at least 3 times and the three closest results are presented as average values.

\section{Results}

\subsection{Cucumbers Production}

At harvest time, all cucumbers had similar aspects regardless of the substrate on which they grew up. The yields obtained in March show statistically significant distinct positive differences for all variants grown on perlite and significant distinct negative differences on variants that used Jiffy substrate culture. This highlights that perlite brings an important earliness increase. Statistically, in April there were no differences between the variants but only to variant cultivated on Perlite $-4 \mathrm{~mm}$ showedvery significant positive differences against the average experience. In May distinct statistically significant negative differences on Perlite $2 \mathrm{~mm}$, Perlite $4 \mathrm{~mm}$ and Perlite $5 \mathrm{~mm}$ were observed, which indicates that production began to decline. For the variants croped on and Jiffy and Jiffy + Perlite $4 \mathrm{~mm}$ distinct statistically significant positive differences against media experiences wewre noted so the tardiness of obtained yields was highlighted (Table 2).

Table 2. Cucumber average productions obtained on different culture substrates

\begin{tabular}{|c|c|c|c|}
\hline \multirow{2}{*}{ Culture substrate } & \multicolumn{3}{|c|}{ Harvests obtained per plant, $\mathrm{kg} / \mathrm{plant}$} \\
\hline & March & April & May \\
\hline Perlite $2 \mathrm{~mm}$ & $1.155 * * *$ & $6.431^{\mathrm{i}}$ & $4.963^{\mathrm{OOO}}$ \\
\hline Perlite $4 \mathrm{~mm}$ & $1.804 * * *$ & $7.811 * *$ & $5.249^{\mathrm{OOO}}$ \\
\hline Perlite $5 \mathrm{~mm}$ & $1.795 * * *$ & $7.166^{\mathrm{i}}$ & $4.914^{\mathrm{OOO}}$ \\
\hline Jiffy & $0.128^{\mathrm{OOO}}$ & $6.026^{\mathrm{i}}$ & $7.963 * * *$ \\
\hline \multirow[t]{4}{*}{ Jiffy + Perlite $4 \mathrm{~mm}$} & $0.474^{\mathrm{OOO}}$ & $6.188^{\mathrm{i}}$ & $7.952 * * *$ \\
\hline & $\mathrm{LD} 5 \%$ in $\%=0.9335$ & $\mathrm{LD} 5 \%$ in $\%=13.1239$ & LD5\% in $\%=1.4499$ \\
\hline & $\mathrm{LD} 1 \%$ in $\%=0.9335$ & $\mathrm{LD} 1 \%$ in $\%=19.1025$ & $\mathrm{LD} 1 \%$ in $\%=2.2554$ \\
\hline & LD $01 \%$ in $\%=1.8671$ & LD $01 \%$ in $\%=28.5809$ & LD01\% in $\%=3.3831$ \\
\hline
\end{tabular}

Note. ***: positive distinct significant; **: positive very significant; ${ }^{\mathrm{OOO}}$ : negative distinct significant; ${ }^{\mathrm{i}}$ : Insignificant; LD: liberty degree. 
The average total production estimated per hectare for each substrate was of $22.59 \mathrm{~kg}$ for Perlite $2 \mathrm{~mm}, 26.76 \mathrm{~kg}$ for Perlite $4 \mathrm{~mm}, 24.98 \mathrm{~kg}$ for Perlite $5 \mathrm{~mm}, 25.41 \mathrm{~kg}$ for Jiffy and $26.31 \mathrm{~kg}$ for Jiffy+Perlite $-4 \mathrm{~mm}$. From statistically point of view, significant negative difference was noted for cultivated variant on Perlite $-2 \mathrm{~mm}$ and meaningful statistically distinct differences on variants grown on Perlite $-4 \mathrm{~mm}$ and Jiffy+Perlite $-4 \mathrm{~mm}$. at The variants cultivated on Perlite $5 \mathrm{~mm}$ and on Jiffy insignificant statistically differences have been recorded compared to the average of experiences (Table 3 ).

Thus, cucumber plants respond to conditions offered by the soilless substrates whereon grown. In terms of fruit production, the substrate Perlite $-4 \mathrm{~mm}$ has the highest production of $26.76 \mathrm{~kg}$ on ha followed closely by Jiffy+Perlite $-4 \mathrm{~mm}$, while the lowest production was obtained on Perlite $-2 \mathrm{~mm}$.

All plants were vigorous, healthy green and had appropriate sizes. However, analyzes had shown that similar look of plants should not be associated with similar concentrations of some biochemical compounds that give fruit quality.

Table 3. Total production obtained per plant and per square meter

\begin{tabular}{lll}
\hline Culture substrate & Total production obtained per plant, kg/plant & Total production, $\mathrm{Kg} / \mathrm{m}^{2}$ \\
\hline Perlite $2 \mathrm{~mm}$ & $12.549^{\circ 00}$ & 22.588 \\
Perlite $4 \mathrm{~mm}$ & $14.864^{* * *}$ & 26.755 \\
Perlite $5 \mathrm{~mm}$ & $13.875^{\mathrm{i}}$ & 24.975 \\
Jiffy & $14.117^{\mathrm{i}}$ & 25.410 \\
Jiffy+Perlite $4 \mathrm{~mm}$ & $14.614^{* * *}$ & 26.305 \\
& LD5\% in $\%=1.2140$ & \\
& LD $1 \%$ in $\%=1.7852$ & \\
\hline LD0 $\%$ in $\%=2.7136$ & \\
\hline
\end{tabular}

Note. ${ }^{* * *}$ : positive distinct significant; ${ }^{* *}$ : positive very significant; ${ }^{000}$ : negative distinct significant; ${ }^{i}$ : Insignificant; LD: liberty degree.

\subsection{Nitrate Content}

Nitrate pollution and excess nitrates in food as a result of intense fertilization is a current issue. Consequently nitrates present in cucumber samples were evaluated in order to see whether or not, the nature of the substrate influences the absorption and retention of nitrate in tissues. Figure 1 presents the results obtained regarding the nitrate concentrations found in leaves, stems and fruits harvested from greenhouse grown cucumbers on the 5 types of substrate. The quantities of nitrates are higher in leaves and stems with two exceptions concerning cucumbers grown on Perlite $5 \mathrm{~mm}$ respectively on Jiffy+Perlite $4 \mathrm{~mm}$. In the first case, the stems have nitrate content higher than on leaves and in the second case the fruits have nitrate content $(15.97 \mathrm{ppm})$ slightly higher than that of stems (14.27 ppm). According to Romanian legislation (Order no 293 of 2 August 2001; Order Nr. 640 of September 19, 2001), cucumbers obtained, on all substrates, have nitrate content well below (around 28.5 times smaller) against the maximum allowable value $(400 \mathrm{ppm})$. Even the nitrate content of leaves and stems is far below the allowed limit. Thus the highest value found for nitrates, the one from the stems of cucumbers grown on Perlite $5 \mathrm{~mm}$, is 8.6 times lower than the amount allowed.

\subsection{Dry Matter Content}

The dry matter content obtained for the different samples is shown in Figure 2. As expected the highest dry matter content is in the leaves, followed by the stems and fruits. There is a similar relationship between dry matter contents to the values obtained from leaves, stems and fruit for all 5 types of substrates. 


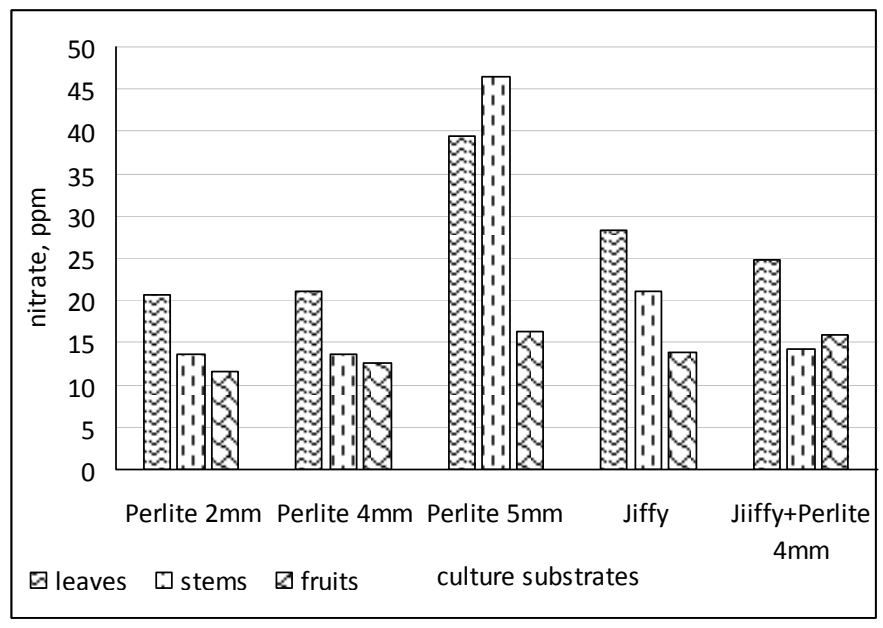

Figure 1. Influence of culture substrates on cucumber leaves, stems and fruits nitrate content

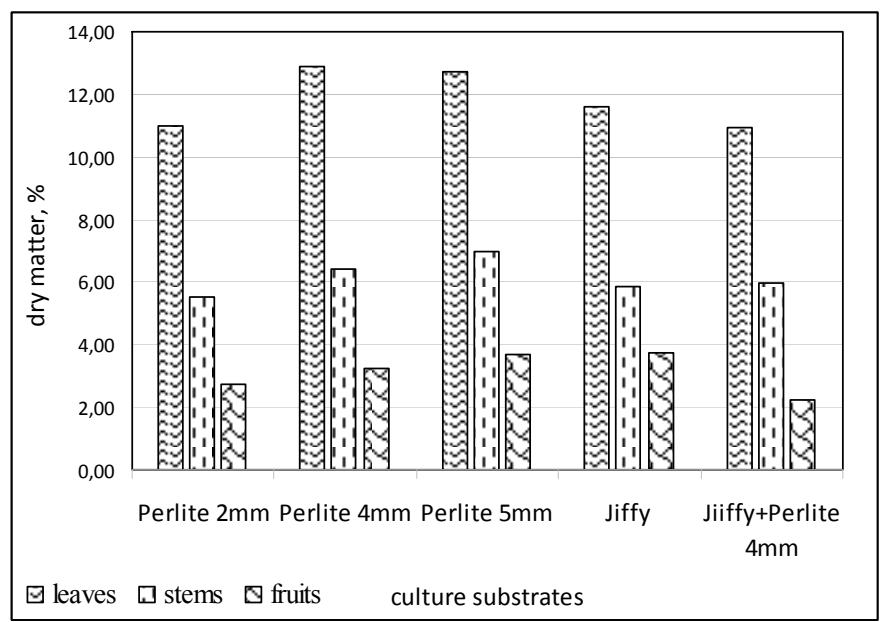

Figure 2. Influence of culture substrates on cucumber leaves, stems and fruits dry matter concentrations

The leaves present the highest dry matter content with values between $10.95 \%$ (Jiffy+Perlite $-4 \mathrm{~mm}$ ) and $12.88 \%$ (Perlite $-4 \mathrm{~mm}$ ). The stems have dry matter content between $5.50 \%$ and $6.98 \%$. For the fruits the smallest content of dry matter is for plant grown on Jiffy+Perlite $-4 \mathrm{~mm}(2.23 \%)$. The highest value was found in the fruits of the harvest obtained from the substrate Jiffy (3.72\%) followed by those obtained on Perlite $-5 \mathrm{~mm}(3.67 \%)$, Perlite $4 \mathrm{~mm}(3.22 \%)$ and Perlite $-2 \mathrm{~mm}(2.75 \%)$ substrates. Because the differences between fruit dry matter concentrations, varies by up to $40 \%$ the influence of culture substrate is obvious.

\subsection{Total Chlorophyll Content}

Total chlorophyll content is as expected highest in leaves. Except for plants grown on the substrate Perlite $-2 \mathrm{~mm}$, on all of the other plants grown on the rest of substrates the total chlorophyll content is close enough to the leaves samples. Total chlorophyll content in stems respectively in fruits is quite low (Figure 3). Thus, the highest total chlorophyll content was found in the leaves of plants grown on the substrate Perlite $-5 \mathrm{~mm}(151.56 \mathrm{mg} / 100 \mathrm{~g})$, followed closely by the ones reared on Jiffy $(150.59 \mathrm{mg} / 100 \mathrm{~g})$ then on Jiffy+Perlite $-4 \mathrm{~mm}(137.54 \mathrm{mg} / 100 \mathrm{~g})$ and on Perlite $-4 \mathrm{~mm}(136.11 \mathrm{mg} / 100 \mathrm{~g})$. Total chlorophyll content in leaves grown on Perlite $-2 \mathrm{~mm}(31.11$ $\mathrm{mg} / 100 \mathrm{~g}$ ) is 4.63 times smaller than the average found in the leaves of plants grown on the others substrates. Total chlorophyll content in stems was of $20.75 \mathrm{mg} / 100 \mathrm{~g}$ (Perlite $-2 \mathrm{~mm}$ ), $14.33 \mathrm{mg} / 100 \mathrm{~g}$ (Jiffy), $12.53 \mathrm{mg} / 100 \mathrm{~g}$ (Perlite $-5 \mathrm{~mm}$ ), $10.14 \mathrm{mg} / 100 \mathrm{~g}$ (Jiffy+Perlite $-4 \mathrm{~mm}$ ) and $5.67 \mathrm{mg} / 100 \mathrm{~g}$ (Perlite $-4 \mathrm{~mm}$ ). Total chlorophyll content in fruits varied between $5.84 \mathrm{mg} / 100 \mathrm{~g}$ and $3.84 \mathrm{mg} / 100 \mathrm{~g}$ values. In general, the ratio of total chlorophyll content from leaves compared to that of stems, respectively on fruit the values are several times higher. Thus in 
respect of cucumber plants grown on Perlite $-5 \mathrm{~mm}$ the chlorophyll content from leaves is about 12.1 higher than the chlorophyll content from stems and 25.95 times higher than in fruits.

\subsection{Protein Content}

Protein content varies both in relation to substrate on which plants grew as well as between the leaves, stems and fruits for the plants on the same crop. However, variations in protein content are not very large (Figure 4).

Thus, protein concentrations in fruits decrease in the order $645.7 \mathrm{mg} / 100 \mathrm{~g}$ (Jiffy), $542.9 \mathrm{mg} / 100 \mathrm{~g}$ (Perlite - 4 $\mathrm{mm}), 535.4 \mathrm{mg} / 100 \mathrm{~g}$ (Perlite $-5 \mathrm{~mm}), 481.1 \mathrm{mg} / 100 \mathrm{~g}$ (Perlite $-2 \mathrm{~mm})$, and $330.6 \mathrm{mg} / 100 \mathrm{~g}$ (Jiffy + Perlite -4 $\mathrm{mm})$. In the leaves, protein concentrations were the highest for all crops, decreasing as follows: $834.9 \mathrm{mg} / 100 \mathrm{~g}$ (Perlite $-5 \mathrm{~mm}), 685.7 \mathrm{mg} / 100 \mathrm{~g}$ (Jiffy+Perlite $-4 \mathrm{~mm}), 683.7 \mathrm{mg} / 100 \mathrm{~g}$ (Perlite $-4 \mathrm{~mm}), 634.9 \mathrm{mg} / 100 \mathrm{~g}$ (Jiffy), and $563.4 \mathrm{mg} / 100 \mathrm{~g}$ (Perlite $-2 \mathrm{~mm})$. The protein content from stems is descending in order $373.1 \mathrm{mg} / 100 \mathrm{~g}$ (Perlite $-2 \mathrm{~mm}), 344.9 \mathrm{mg} / 100 \mathrm{~g}$ (Perlite $-4 \mathrm{~mm}), 201.7 \mathrm{mg} / 100 \mathrm{~g}$ (Perlite $-5 \mathrm{~mm}), 187.7 \mathrm{mg} / 100 \mathrm{~g}$ (Jiffy) and $187.1 \mathrm{mg} / 100 \mathrm{~g}$ (Jiffy+Perlite $-4 \mathrm{~mm})$.

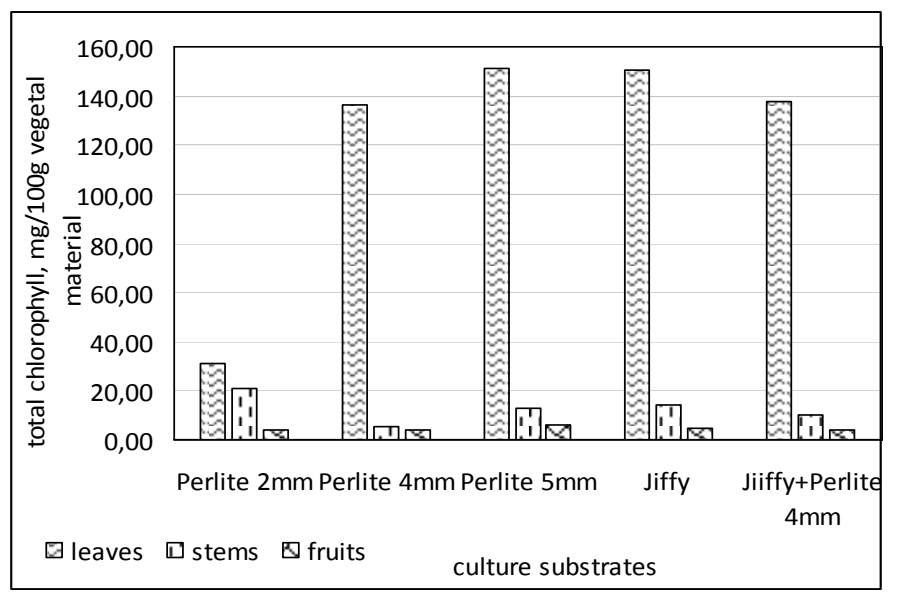

Figure 3. Influence of culture substrates on cucumber leaves, stems and fruits on total chlorophyll content

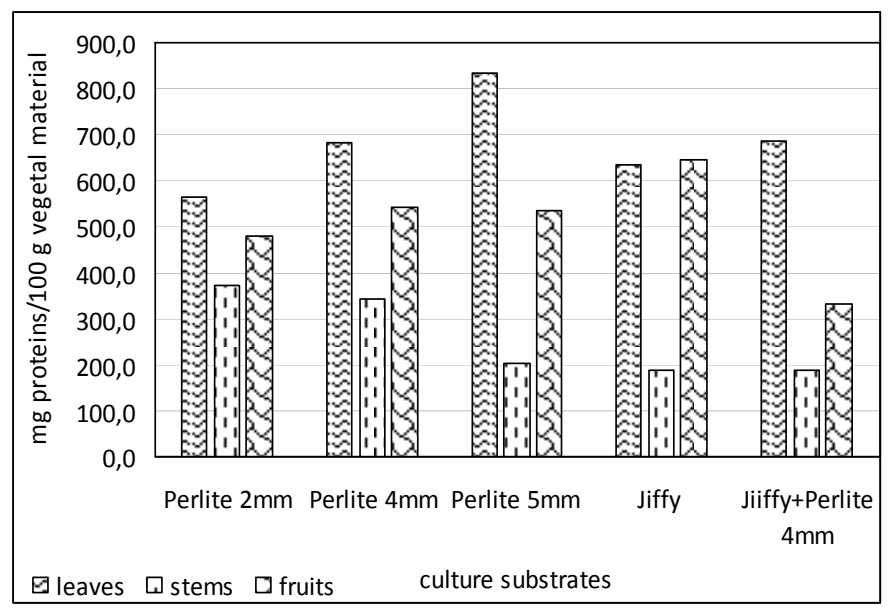

Figure 4. Influence of culture substrates on cucumber leaves, stems and fruits on protein concentrations

\subsection{Reducing Sugars Content}

Carbohydrates are usually analyzed compounds in vegetables and fruits. Cucumbers grown on different substrates show different concentrations of carbohydrates, determined as reducing sugars. The results presented in Figure 5. show that cucumbers grown on substrate Jiffy have the highest concentration of reducing sugars in fruits (726.6 $\mathrm{mg} / 100 \mathrm{~g})$ compared to those obtained on the other substrates. The reducing sugars content in stems $(8.0 \mathrm{mg} / 100 \mathrm{~g})$ and leaves $(12.9 \mathrm{mg} / 100 \mathrm{~g})$ are very low. The same type of relation between the concentration of reducing sugars 
from fruits $(433.8 \mathrm{mg} / 100 \mathrm{~g})$, leaves $(12.9 \mathrm{mg} / 100 \mathrm{~g})$ and stems $(15.9 \mathrm{mg} / 100 \mathrm{~g})$, although presenting smaller values, appears in crops grown on the substrate Perlite $-4 \mathrm{~mm}$ too. Samples taken from crops grown on the substrate Perlite $-2 \mathrm{~mm}$ is different from other cultures because presence of reducing sugars in leaves, fruits and stems is quite high both in fruits $(541.7 \mathrm{mg} / 100 \mathrm{~g})$, in leaves $(367.8 \mathrm{mg} / 100 \mathrm{~g})$ and stems $(501.9 \mathrm{mg} / 100 \mathrm{~g})$. Samples taken from crops grown on the substrate Perlite $-5 \mathrm{~mm}$ have high enough concentrations of reducing sugars in fruits $(514.9 \mathrm{mg} / 100 \mathrm{~g})$ and stems $(198.8 \mathrm{mg} / 100 \mathrm{~g})$ but lower in leaves $(44.7 \mathrm{mg} / 100 \mathrm{~g})$. The lowest reducing sugars concentrations were found in samples taken from crops grown on the substrate Jiffy+Perlite -4 $\mathrm{mm}$ (fruits $-277.3 \mathrm{mg} / 100 \mathrm{~g}$; leaves $-218.7 \mathrm{mg} / 100 \mathrm{~g}$; stems $-3.0 \mathrm{mg} / 100 \mathrm{~g}$ ). It is important to note that the concentration of reducing sugars in plants is clearly influenced by the nature of the substrate on which they grew. Thus, from terms of reducing sugars content, the decreasing order of culture substrates is Jiffy, Perlite $-2 \mathrm{~mm}$, Perlite $-5 \mathrm{~mm}$, Perlite $-4 \mathrm{~mm}$ and Jiffy + Perlite $-4 \mathrm{~mm}$.

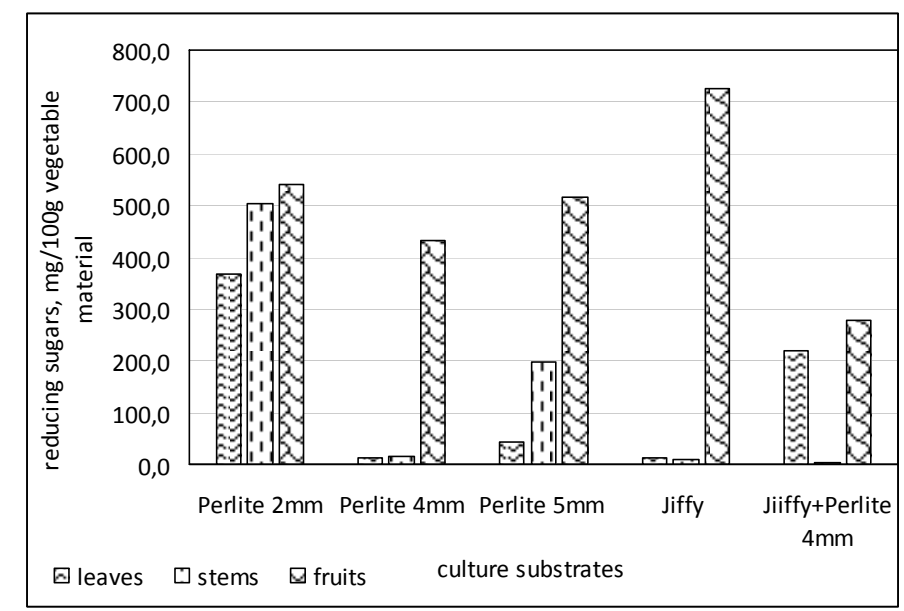

Figure 5. Concentrations of reducing sugars in leaves, stems and fruits of cucumber plants grown on different hydroponic substrates

\subsection{Invertase Activity}

The invertase activity was determined to see if the nature of the culture substrate affects it or not. The results are presented in Figure 6.

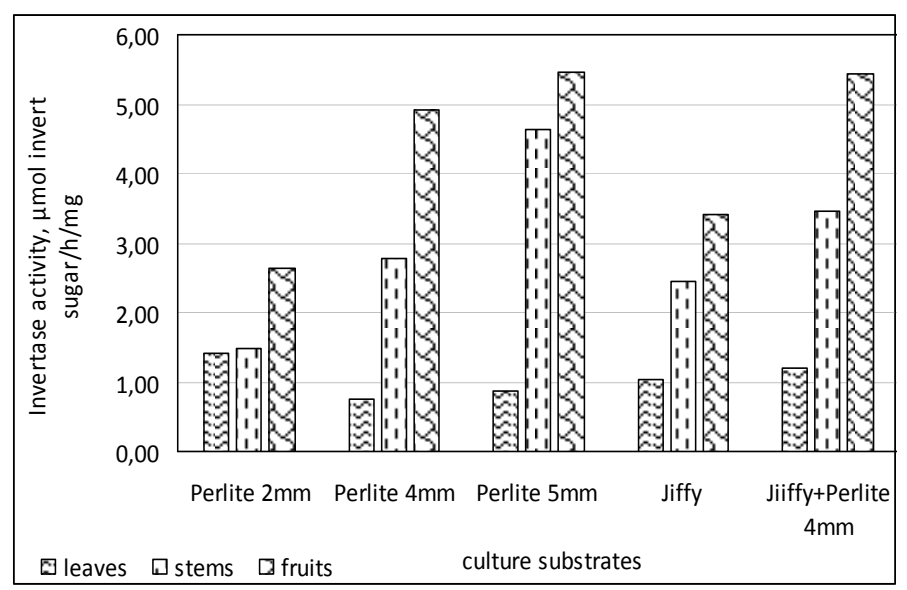

Figure 6. Invertase activity in leaves, stems and fruits of cucumber plants grown on different hydroponic substrates

It is clear that the neutral invertase activity is correlated with the content of reducing sugars in fruits are much more active than in the leaves or stems. The exception is the case of plants grown on the substrate Perlite $2 \mathrm{~mm}$ substrate. 
In these plants the concentration of reducing sugars from the leaves and stems is much higher compared to the other plants rowed on other substrates. At the same time, the enzymatic activity is similar in size to those corresponding to leaves and stems of plants grown on other substrates. The explanation lies in the structure of this substrate. Small particles $(2 \mathrm{~mm})$ creates a density that determines besides a hypoxia phenomenon a restriction of root development therefore stress which reduces the possibility of optimal development of plants.

\section{Discussion}

Coordination between the crops and the properties of each substrate, mainly the aeration capacity, is obvious. However productivity differences are enough small relative to the 5 types of substrate. The only productivity that stands out as being smaller than the other is the one obtained on Perlite $-2 \mathrm{~mm}$ substrate. The nutrient solution used was the same for all types of substrate and it pursued as nutrients to be in the same concentration throughout the development stage of cucumber plants. So, although the availability of nutrients was the same for all substrates, the growth, maturation and production of plants developed on Perlite $2 \mathrm{~mm}$ were lower against the results obtained for the all other substrate. The explanation reside in the small dimension of particle which determine a slowly flow of the nutrient solutions and especially reduced capacity of absorption and aeration. A similar conclusion was obtained by Robbins and Pharr in a study regarding the influence of container volumes on growth of cucumber plants (Robbins \& Pharr, 1988).

It should be emphasized that fruit development is faster on Perlite, mainly on Perlite $4 \mathrm{~mm}$ than on Jiffy substrates which brings a benefit in terms of trade since cucumber prices are higher in March and April than in May. A coordination between the crops and the properties of each substrate, mainly the aeration capacity, is obvious. However productivity differences are enough small relative to the 5 types of substrate.

Thus, from productivity point of view the best results, both in terms of earliness and total production per plant were obtained for the substrate Perlite $4 \mathrm{~mm}$.

Until now, there has been little studies related to influence of substrates on different compounds of cucumbers (Cucumis sativus). In this context, in our study we followed the content of nitrate, chlorophyll, dry matter, reducing sugars, protein and invertase. Nitrate content was assessed because, currently due to health problems caused by excess nitrates in food and water, it is mandatory that the content to be kept below the limits set by the laws in force in each country. Chlorophyll is vital for photosynthesis processes, process by which plants manufacture biochemical components that give them quality, taste, texture, firmness. Dry matter, protein and reducing sugars content were analyzed because these are some of the mainly biochemical compounds that give fruit quality. The invertase activity was assessed because it shows degree of maturity and ripening of fruit. So, as this activity decreases and the concentration of reducing sugars increases the more the fruit is ripe, with a majority of carbohydrates consisting of sugar, glucose or fructose.

The excess of nitrate in food is nowadays an issue because in many plants grown in greenhouses (such as lettuce or tomatoes) the nitrate level exceeds the maximum admissible concentration. The analyzes performed in this study shows, however, that the maximum nitrate was not exceeded in any of the soilless substrates used. Even if the levels of nitrate concentrations in leaves and stems are higher than in fruits, either these do not exceed the maximum limit allowed. The highest accumulations of nitrate occur in leaves, stems and fruits of plants grown on Perlite $5 \mathrm{~mm}$ substrate. For all substrates the nitrate concentrations are higher in leaves, followed by stems and fruits. Exceptions are stems of plants grown on Perlite $-5 \mathrm{~mm}$ where nitrate concentrations are slightly higher than in leaves and fruits and for plants grown on Jiffy+Perlite $-4 \mathrm{~mm}$ where nitrate concentration is slightly higher in fruits than in stems (Figure 1). Nitrates are involved in amino-acids and proteins synthesis. Thus, it is expected that a higher assimilation of nitrates will increase the protein content. Indeed, in the leaves of cucumber is a direct correlation between nitrate content and protein for all types of substrates used. For stems and fruits, this correlation does not appear strictly direct. For example, the nitrate content of fruit plants grown on Perlite - 5mm is the largest $(16.31 \mathrm{ppm})$ but the protein content is only very slightly higher than that found in fruits of plants grown on Perlite $-4 \mathrm{~mm}$ whose nitrate content was only of $12.57 \mathrm{ppm}$. This can be explained by the level of activity of nitrate reductases (Paul \& Stitt, 1993; Ruiz \& Romero, 2000) and lower protein synthesis (Figure 4). The same behavior appears for fruits of plants grown on Jiffy+Perlite $-4 \mathrm{~mm}$. Thus, from the nitrate content point of view, all fruits are safely and regarding the protein accumulation the best results have been obtained at plants cultivated on Jiffy followed by Perlite $-4 \mathrm{~mm}$ substrate. So, it is preferred to use the Perlite $-4 \mathrm{~mm}$ substrate taking into account that the Jiffy price is several times higher than of Perlite $-4 \mathrm{~mm}$. Relatively high concentrations of protein in the leaves and fruits could mean the presence of various enzymes in these tissues. Thus, further study on the influence of culture substrates on various possibly to be present enzymes, it is necessary, especially because such studies are relatively few so far, especially by comparing the protein content according to 
different cultivation substrates.

The highest dry matter content in leaves is normal taking into account the fact that in the leaves most metabolic processes take place. Consequently, here are the pigments involved in photosynthesis, resulted carbohydrates by photosynthesis as well as proteins for example thoseinvolved in metabolic processes. The stems contain a considerable amount of cellulose so it is normal that dry matter to will be in higher amount-than in fruits. Thus in terms of dry matter accumulation, the substrates Jiffy and Perlite $-5 \mathrm{~mm}$ are the best. But, because of the price and availability, the substrate Perlite $5 \mathrm{~mm}$ is preferred over Jiffy substrate.

Chlorophyll is an extremely important biomolecule, occupying a central place in photosynthesis so in metabolic processes. Thus it is important to know if growing media influence total chlorophyll content in plants. Our results show the highest presence of chlorophyll especially in leaves as expected. The lowest chlorophyll concentrations were found in fruits. Also, and in the case of fruits the highest content was found in fruits of plants grown on Perlite $5 \mathrm{~mm}$ followed by in those grown on Jiffy. The lowest chlorophyll content of the whole plant, and especially in leaves was found in plants grown on Perlite $2 \mathrm{~mm}$. The explanation of this phenomenon could be considered the reduced aeration capacity of this substrate in the root areas (Robbins \& Pharr, 1988).

Given the different concentrations of chlorophyll both in leaves as well as in stems respectively in fruits the influence of substrates is evident.

Carbohydrates are the primary molecules to provide energy and to contribute in many metabolic processes. Generally the development and growth of plants is closely linked to sugar contents. Even if a number of studies regarding the influence of carbohydrate content on plant growth were carried out and a number of theories were developed, yet it is not exactly known how the content and nature of carbohydrates affect growth (Smeekens, Ma, Hanson, \& Rolland, 2010). Our analyses show concentrations of reducing sugars in fruits significantly higher than those in stems or leaves. The only exception was found on plants grown on Perlite $2 \mathrm{~mm}$ where the reducing sugar concentrations of fruits, leaves and stems are quite close.

Numerous studies have shown the crucial role of sucrose in plant metabolism. Thus, sucrose is involved in the process of photosynthesis, pigment synthesis control, in nitrogen metabolism, defense against pathogens and in controling of its own synthesis. Therefore, the role of sucrose is of major importance in plant life. In this extremely broad and varied of action of sucrose signaling molecule there are some gaps in knowledge. For example, it is not known for sure whether the actions of this molecule are assigned to sucrose itself or to its degradation products, namely monosaccharides resulted under the action of invertase. Cleavage of sucrose, an invertase catalyzed hydrolysis, is vital for plants, occupying a central place in plant carbon metabolism. Our results clearly shows the correlation between invertase activity and the content of reducing sugars, results confirmed by other different authors (Tognetti, Pontis, \& Martínez-Noël, 2013; Wind, Smeekens, \& Hanson, 2010; Koch, 2004; Winter \& Huber, 2000; Tauzin \& Giardina, 2014).

\section{Conclusion}

Crop productions and concentration of biochemical compounds in their leaves, stems and fruits largely depend on substrate culture nature. From agronomical point of view the highest productivity was obtained on Perlite $-4 \mathrm{~mm}$ followed by Jiffy+Perlite $-4 \mathrm{~mm}$, Jiffy, Perlite $-5 \mathrm{~mm}$ and Perlite $-2 \mathrm{~mm}$ substrates. In addition the earliest production was obtained on Perlite $-4 \mathrm{~mm}$ substrate too.

Although the productions on Jiffy and Jiffy+Perlite $-4 \mathrm{~mm}$ substrates are next best optipons after Perlite- $4 \mathrm{~mm}$ substrate these are not advantageous because the nutritional quality of fruits is practically the lowest.

The nitrate levels are below the maximum allowable limit for all cultures and for different tissues too as a result of maintaining the fertilizers concentration just to the necessary level.

In terms of different biochemical compounds, as a general aspect the best results were fopund on the plants grown on Jiffy followed by Perlite $-5 \mathrm{~mm}$ and very close on Perlite $-4 \mathrm{~mm}$ substrates. It is interesting that Jiffy+Perlite $-4 \mathrm{~mm}$ substrate does not offer a combination of the two substrates qualities. In fact, the fruits grown on this substrate had the lowest nutitional value. Reduced particle size of Perlite $-2 \mathrm{~mm}$ substrate are causing a reduced aeration to roots level and therefore a slow development, respectively a lower production and a poor biochemical compounds concentration.

Thus, taking into account the price and the availability of substrates, as well the productivity and the global biochemical composition for cucumber crops, only Perlite $-4 \mathrm{~mm}$ substrate can be recommended.

As a general conclusion, a deeper research regarding the evolution of biochemical compounds and their metabolism in plant rowon on different substrates is necessary. 


\section{Acknowledgements}

This work was supported by a grant of the Romanian National Authority for Scientific Research, CNDI-UEFISCDI, financed from project number PN-II-PT-PCCA-2011-3.2-1351-Contract No. 68/2012 and the European Social Found, Human Resources Development Operational Programme 2007-2013, project no. POSDRU/159/1.5/S/13276.

\section{References}

Ghehsareh, A. M., Hematian, M., \& Kalbasi, M. (2012). Comparison of date-palm wastes and perlite as culture substrates on growing indices in greenhouse cucumber. International Journal of Recycling Waste in Agriculture, 1(5). http://dx.doi.org/10.1186/2251-7715-1-5

Gül, A. (1999). Investigations on effects of media and bag volume on cucumbers. CIHEAM, Options Mediterraneennes Cahiers Options Mediterraneennes, 31, 371-378.

Hartree, E. F. (1972). Determination of protein: A modification of the Lowry method that gives a linear $\begin{array}{lllll}\text { photometric } \quad \text { response. } & \text { Analytical } & 422-427 .\end{array}$ http://dx.doi.org/10.1016/0003-2697(72)90094-2

Herskovitch, D., \& Lin, I. J. (1996). Upgrading of Raw Perlite by a Dry Magnetic Technique. Magnetic and Electrical Separation, 7(3), 145-161. http://dx.doi.org/10.1155/1996/58505

Hochmuth, R. C. (2012). Greenhouse Cucumbers Production. Florida Greenhouse Vegetable Production Handbook (Vol. 3, HS790). Horticultural Sciences Department, Florida Cooperative Extension Service, Institute of Food and Agricultural Sciences, University of Florida, Gainsville, Florida. Retrieved from http://edis.ifas.ufl.edu

Inskeep, W. P., \& Bloom, P. R. (1985). Extinction Coefficients of Chlorophyll a and b in N,N-dimethylformamide and 80\% Acetone. Plant Physiology, 77, 483-485. http://dx.doi.org/10.1104/pp.77.2.483

Inthichack, P., Nishimura, Y., \& Fukumoto, Y. (2014). Effect of Diurnal Temperature Alternations on Plant Growth and Mineral Composition in Cucumber, Melon and Watermelon. Pakistan Journal of Biological Sciences, 17, 1030-1036. http://dx.doi.org/10.3923/ojbs.2014.1030.1036

ISO 751. (1998). Fruit and vegetable products - Determination of water-insoluble solids. Retrieved from http://www.iso.org/iso/home/store/catalogue_ics

Koch, K. (2004). Sucrose metabolism: regulatory mechanisms and pivotal roles in sugar sensing and plant development. Current Opinion in Plant Biology, 7(3), 235-246. http://dx.doi.org/10.1016/j.pbi.2004.03.014

Lowry, O. H., Rosenbrough, N. J., Farr, A. L., \& Randall, R. J. (1951). Protein measurements with the folin phenol reagent. Journal of Biological Chemistry, 193, 265-275.

Mi, G., Liu, L., Zhang, Z., \& Ren, H. (2012). Changes in photosynthesis and activities of enzymes involved in carbon metabolism during exposure to low light in cucumber (Cucumis sativus) seedlings. African Journal of Biotechnology, 11(34), 8537-8545.

Miller, G. L. (1959). Use of dinitrosalicylic acid reagent for determination of reducing sugar. Analytical Chemistry, 31, 426-428. http://dx.doi.org/10.1021/ac60147a030

Moran, R. (1982). Formulae for determination of chlorophyllous pigments extracted with NN-dimethylformamide. Plant Physiology, 69, 1376-1381. http://dx.doi.org/10.1104/pp.69.6.1376

Official Monitor Nr. 173. (2002). Order No. 293 of August 2, 2001 of the Ministry of Agriculture, Food and Forestry and Order No. 640 of September 19, 2001 of the Ministry of Health and Family.

Palanna, O. G. (2009). Engineering Chemistry (pp.272-273). Tata McGraw Hill Education Private Limited.

Paul, M. J., \& Stitt, M. (1993). Effects of nitrogen and phosphorous deficiencies on levels of carbohydrates, respiratory enzymes and metabolites in seedlings of tobacco and their response to exogenous sucrose. Plant, Cell and Environment, 16, 1047-1057. http://dx.doi.org/10.1111/j.1365-3040.1996.tb02062.x

Robbins, N. S., \& Pharr, D. M. (1988). Effect of Restricted Root Growth on Carbohydrate Metabolism and Whole Plant Growth of Cucumis sativus L. Plant Physiology, 87, 409-413. http://dx.doi.org/10.1104/pp.87.2.409

Ruiz, J. M., \& Romero, L. (2000). Nitrogen metabolism and yield response of cucumber (Cucumis sativus L. cv Brunex) plants to phosphorus fertilisation. Journal of the Science of Food and Agriculture, 80, 2069-2073. http://dx.doi.org/10.1002/1097-0010(200011)80:14\%3C2069::AID-JSFA749\%3E3.0.CO;2-7 
Rybus-Zając, M., Kubiś, J., \& Bocianowski, J. (2014). UV-B radiation does not limit carbohydrate level and carbohydrate metabolism in cucumber leaves. Communications in Biometry and Crop Science, 9(1), 3-14.

Shaw, N. L., Cantliffe, D. J., Funes, J., \& Shine, C. III. (2004). Successful Beit Alpha Cucumber Production in the Greenhouse Using Pine Bark as an Alternative Soilless Media. HortTechnology, 14(2), 289-294.

Smeekens, S., Ma, J., Hanson, J., \& Rolland, F. (2011). Sugar signals and molecular networks controlling plant growth. Current Opinion in Plant Biology, 13, 274-279. http://dx.doi.org/10.1016/j.pbi.2009.12.002

Tauzin, A. S., \& Giardina, T. (2014). Sucrose and invertases, a part of the plant defense response to the biotic stresses. Frontiers in Plant Science, 5(293). http://dx.doi.org/10.3389/fpls.2014.00293

Tognetti, J. A., Pontis, H. G., \& Martínez-Noël, G. M. A. (2013). Sucrose signaling in plants: A world yet to be explored. Plant Signal \& Behavior, 8(3), e23316. http://dx.doi.org/10.4161/psb.23316

Wang, L. N., Yang, X. Y., Ren, Z. H., \& Wang, X. F. (2014). Regulation of photoassimilate distribution between source and sink organs of crops through light environment control in greenhouses. Agricultural Sciences, 5, 250-256. http://dx.doi.org/10.4236/as.2014.54028

Wang, N. S. (2009). Experiment no. 14 - Enzyme kinetics of invertase, via initial rate determination. Retrieved from http://www.eng.umd.edu/ nsw/ench485/lab14.htm

Wind, J., Smeekens, S., \& Hanson, J. (2010). Sucrose: Metabolite and signaling molecule. Phytochemistry, 71, 1610-1614. http://dx.doi.org/10.1016/j.phytochem.2010.07.007

Winter, H., \& Huber, S. C. (2000). Regulation of sucrose metabolism in higher plants: Localization and regulation of activity of key enzymes. Critical Reviews in Biochemistry and Molecular Biology, 35(4), 253-289. http://dx.doi.org/10.1080/10409230008984165

Yang, Z.-M., Zheng, S.-J., Hu, A.-T., Zheng, Y.-F., \& Yan, J.-Y. (2000). Responses of cucumber plants to increased uv-B radiation under water stress. Journal of Environmental Sciences, 12(2), 236-240.

Zhou, X. G., Wu, F. Z., \& Xiang, W. S. (2014). Syringic acid inhibited cucumber seedling growth and changed rhizosphere microbial communities. Plant, Soil and Environment, 60(4), 158-164.

\section{Copyrights}

Copyright for this article is retained by the author(s), with first publication rights granted to the journal.

This is an open-access article distributed under the terms and conditions of the Creative Commons Attribution license (http://creativecommons.org/licenses/by/3.0/). 